\author{
M. Kovalenko ${ }^{1,2}$, O. Bovgyra ${ }^{1}$, V. Dzikovskyi ${ }^{1,2}$, A. Kashuba ${ }^{2}$, H. Ilchuk ${ }^{2}$, \\ R. Petrus ${ }^{2}$, I. Semkiv ${ }^{2}$
}

\title{
Effect of Al Doping on Optical Properties of ZnO Thin Films: Theory and Experiment
}

\author{
${ }^{1}$ Ivan Franko National University of Lviv, Lviv, Ukraine, mariya.kovalenko@lnu.edu.ua \\ ${ }^{2}$ Lviv Polytechnic National University, Lviv, Ukraine, andriykashuba07@ gmail.com
}

\begin{abstract}
The structural, electronic, and optical properties of zinc oxide thin films with Al-doping have been investigated experimentally and with density functional theory (DFT) calculations. Changes in properties of doped thin films, which are deposited on a glass substrate by a high-frequency magnetron sputtering method, are monitored using X-ray diffraction data and UV measurements. Our theoretical calculations show that the electronic structure of $\mathrm{ZnO}$ : $\mathrm{Al}$ can be well described by the DFT+U method. The XRD measurements demonstrated the formation of a pure single $\mathrm{ZnO}$ phase and $\mathrm{Al}$ atoms is well incorporated in the $\mathrm{ZnO}$ lattice. Also, we determine the optical constants such as optical dielectric function, refractive index, optical band gap values, extinction coefficient, and optical conductivity of the doping films through transmittance spectra. The calculated results show the change of lattice parameters Al-doped $\mathrm{ZnO}$. The optical band gap of $\mathrm{ZnO}$ : $\mathrm{Al}$ is increased compared with pure $\mathrm{ZnO}$. Besides, around the Fermi level of Al-doped $\mathrm{ZnO}$ was emerged the shallow donor states from mainly $3 \mathrm{~s}-\mathrm{Al}$ states. Our DFT calculations of optical properties Al-doped $\mathrm{ZnO}$ agree satisfactorily with the experimentally measured transmittance values.
\end{abstract}

Keywords: Al-doped $\mathrm{ZnO}$, DFT+U, optical band gap, optical properties.

Received 28 January 2021; Accepted 1 March 2021.

\section{Introduction}

The zinc oxide $(\mathrm{ZnO})$ is well known as a wide-band semiconductor with a bandgap $=3.44 \mathrm{eV}$ and exists in the hexagonal wurtzite-type form under normal conditions [1]. The ZnO-based materials have many prospective implementations in various spintronic and optoelectronic devices involving light-emitting diodes, lasers, photodetectors, solar cells, magnetic memory devices, etc. Also, their remarkable structural, electronic, sensor, optical, and electrical properties, together with a large number of different preparation methods appropriate to the production of a high-quality film make them one of the most all-purpose materials in nowadays technology [2]. An efficient method for enhancing the electric and optical characteristics of $\mathrm{ZnO}$ is doping them thin film of impurities [3]. Among different kinds of doped $\mathrm{ZnO}$, aluminum-doped $\mathrm{ZnO}(\mathrm{ZnO}: \mathrm{Al})$ is a cheap, most stable material, has great electric and optical properties, and environmentally friendly, which causes considerable scientific interest. The $\mathrm{ZnO}$ : $\mathrm{Al}$ has wide possible applications as potential solar cell electrodes [4], transparent conductive oxide, and electrical conductivity [5], optoelectronic and photonic devices [6]. Among numerous techniques of growth of thin films, magnetron sputtering is one of the most favored methods for growing $\mathrm{ZnO}$ films because of its simpleness, low operating temperature, and low cost.

In this work, we report experimental and theoretical investigations of the structural and optical properties of Al-doped $\mathrm{ZnO}$ thin films. $\mathrm{ZnO}$ : Al thin films were synthesized by the magnetron sputtering method. Additionally, we model a $3 \times 3 \times 3 \mathrm{ZnO}$ supercell to perform a theoretical study of Al-doped $\mathrm{ZnO}$ using the first-principles method, including examination of electronic structures and optical properties. Using these results, we presented the possibility of using calculated 
results to explain experimental data and indicate a definite theoretical direction for the research of $\mathrm{ZnO}$ based doped structures.

\section{Experimental details}

Al-doped $\mathrm{ZnO}(\mathrm{ZnO}: \mathrm{Al})$ thin films were deposited on glass substrates with a size of $16 \times 8 \times 1.1 \mathrm{~mm}^{3}$ by the method of high-frequency (HF) magnetron sputtering $(\sim 13.6 \mathrm{MHz}$ ) using a VUP-5M vacuum station (Selmi, Ukraine) [7, 8]. As a target, the disc from sintered $\mathrm{ZnO}$ (purity of $99.99 \%$ ) powder with $\mathrm{Al} 2 \mathrm{O} 3$ (2.5 wt.\%) admixture was used. The target-substrate distance was equal to $60 \mathrm{~mm}$. The start and end of the sputtering process were controlled by means of a movable shutter.

Before the sputtering process, the chamber was pumped out. The gas pressure inside the chamber during the film sputtering was equal to $4 \times 10^{-4} \mathrm{~Pa}$. This pressure is achievable when using a polyphenyl ether $(5 \mathrm{~F} 4 \mathrm{E})$ as a diffusion fluid in the vapor oil vacuum pump, which possesses a low vapor pressure of $9 \times 10^{-7} \mathrm{~Pa}$.

The power of the HF magnetron was maintained at the level of $30 \mathrm{~W}$ and the temperature of the substrate at $\sim 373 \mathrm{~K}$. For heating the substrates a high-temperature tungsten heater with a power of $300 \mathrm{~W}$ was used. The temperature was controlled using a proportionalintegral-derivative (PID) controller for controlling heating and cooling rates, as well as for ensuring the temperature conditions of deposition.

The phase analysis and crystal structure refinement was examined using X-ray diffraction data (XRD) obtained on DRON-2.0M diffractometer at room temperature with the $\mathrm{K} \alpha$ radiation $(\lambda=1.936087 \AA)$ of $\mathrm{Fe}$.

\section{Computational methodology}

In this work, the total energies calculations were carried out using the first-principles method within density functional theory (DFT) and implemented in the QUANTUM-ESPRESSO package [9]. Exchange and correlation interactions are described using the generalized gradient approximation (GGA) in combination with ultrasoft pseudopotentials [10]. The considered valence electron are $3 \mathrm{~d}^{10} 4 \mathrm{~s}^{2}$ for $\mathrm{Zn}, 2 \mathrm{~s}^{2} 2 \mathrm{p}^{4}$ for $\mathrm{O}$ and $3 \mathrm{~s}^{2} 2 \mathrm{p}^{1}$ for $\mathrm{Al}$, respectively. Before property calculations were performed structure optimization of pure and doped $\mathrm{ZnO}$ using the Broyden-FletcherGoldfarb-Shannon minimizer [11-14]. Well known that GGA suffers from the unavoidable underestimate of bandgap [15], and this difficulty may manipulate the accuracy of the calculated bandgap. To correct the deviation from bandgap many previous works used approximation with Hubbard corrections or the so-called $\mathrm{DFT}+\mathrm{U}$ [16-18]. When considering calculations for $\mathrm{ZnO}$, GGA underestimates the $\mathrm{Zn} 3 \mathrm{~d}$ electrons energy. The top of the valence band forms with the pair $\mathrm{Zn}$ d-states and $\mathrm{O}$ p-states shifting upwards and essentially narrowing the bandgap [19]. Including the Hubbard U corrections to calculating the insufficient binding of the $\mathrm{Zn}$ d electrons lead to adjust the position of the restricted $d$ states and impacts both the valence band maximum (VBM) and the conduction band minimum (CBM) [16]. In this study were used two Hubbard $U$ corrections: $U_{d}$ for $3 d$ states of $\mathrm{Zn}$ and $U_{\mathrm{p}}$ for $2 \mathrm{p}$ states of $\mathrm{O}$. Using two $U$ values which are equal to $\mathrm{U}_{\mathrm{d}}=10 \mathrm{eV}$ and $\mathrm{U}_{\mathrm{p}}=7 \mathrm{eV}$ lead to the bandgap of pure $\mathrm{ZnO}$ is $3.4 \mathrm{eV}$ which in turn is excellent agreement with experimental data [20]. In this methodology, we were successfully tested on many objects of different dimensions [21-25].

\section{Results and discussion}

\subsection{Experimental results}

$\mathrm{ZnO}$ :Al thin film crystallizes in hexagonal structure (structure type - $\mathrm{ZnO}$, space group $P 6_{3} m c$ (No. 186), with the unit-cell dimensions $a=3.226(2) \AA$ and $c=5.155(6) \AA\left(V=46.49(6) \AA^{3}\right)$. No additional peaks (from X-ray analysis) belonging to other oxides can be detected thereby indicating the formation of pure single $\mathrm{ZnO}$ phase, as well as that $\mathrm{Al}$ is well incorporated within $\mathrm{ZnO}$ lattice.

Then by plotting $(\alpha \cdot h v)^{2}$ versus $h v \quad(\alpha \cdot$ is the absorption coefficient and $h v$ is the photon energy) one has a possibility to obtain the direct optical band gap $E_{\mathrm{g}}$ from extrapolation of the linear part of the plot to the photon energy axis (see Fig. 1). The estimated optical band gap of the $\mathrm{ZnO}: \mathrm{Al}$ thin films has been found to be equal to $E_{\mathrm{g}}=3.26 \mathrm{eV}$.

To determine the thickness of the films under investigation, we can use the following equation:

$$
d=\frac{M \cdot \lambda_{1} \cdot \lambda_{2}}{2 \cdot\left(n\left(\lambda_{1}\right) \cdot \lambda_{2}-n\left(\lambda_{2}\right) \cdot \lambda_{1}\right)},
$$

where, $\lambda_{1}$ and $\lambda_{2}$ are wavelengths corresponding to neighboring extreme points in the transmission spectrum and $M=1$ for two neighboring extrema of one type (max-max, min-min) and $M=0.5$ for two neighboring extrema of opposite types (max-min, min-max). The obtained value of the $\mathrm{ZnO}$ : $\mathrm{Al}$ thin film thickness is $454.83 \mathrm{~nm}$.

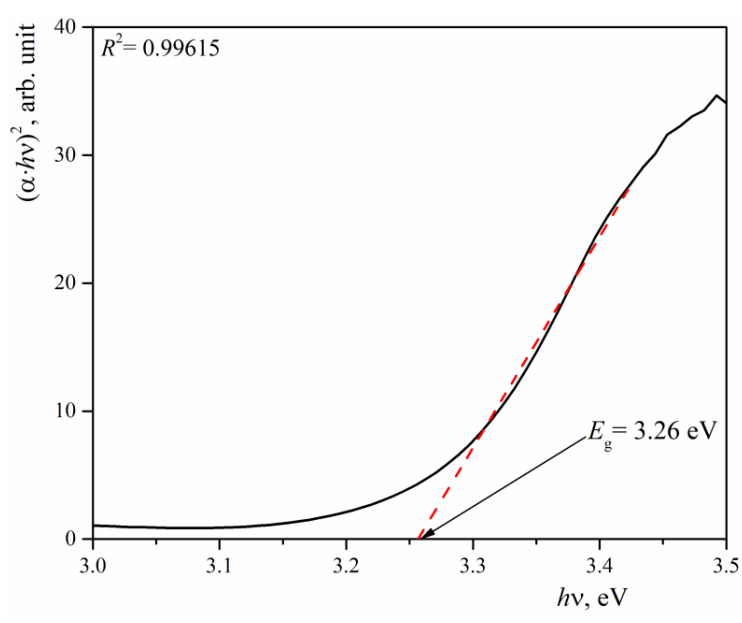

Fig. 1. The spectral dependence of optical absorption for the $\mathrm{ZnO}: \mathrm{Al}$ thin films. 

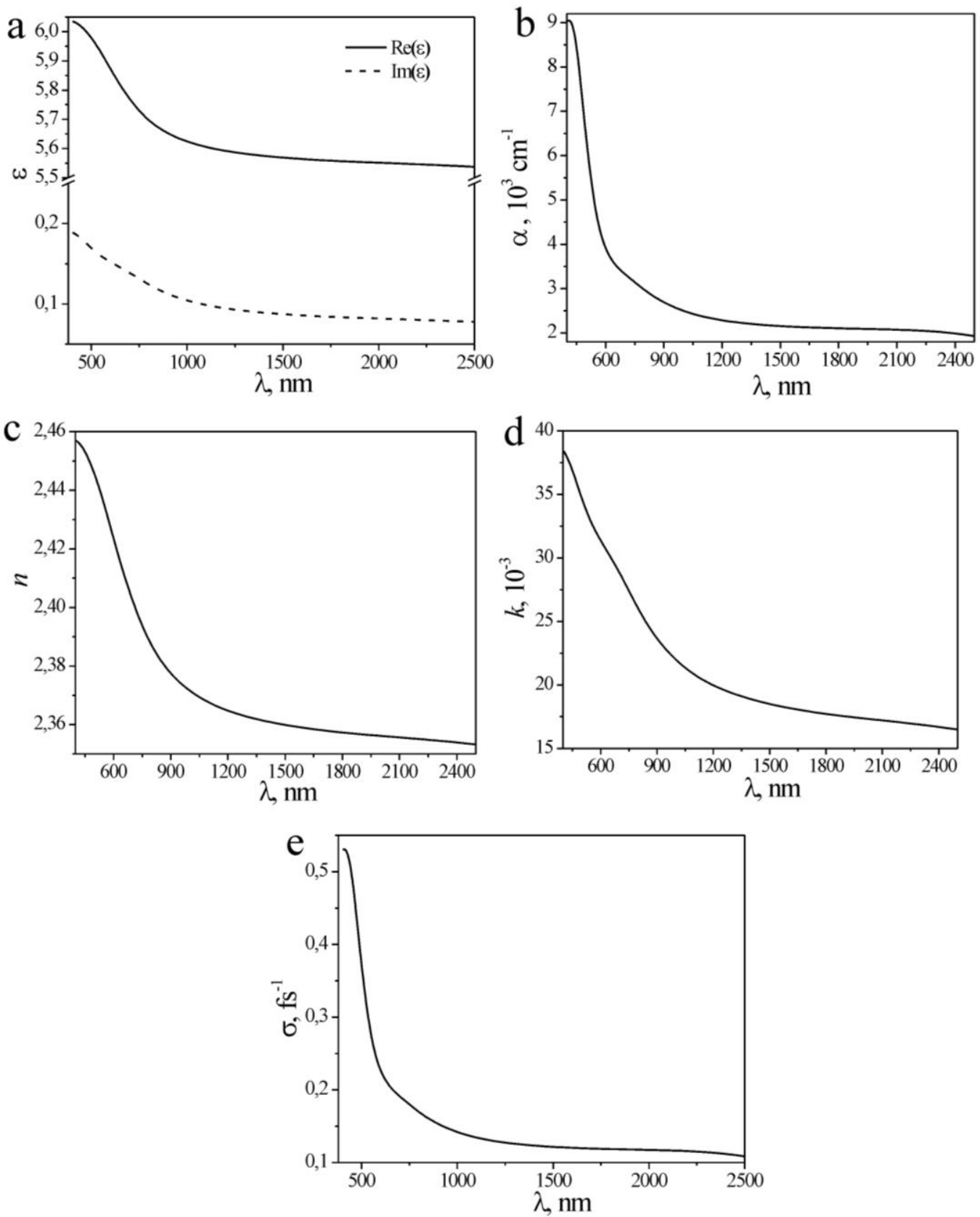

Fig. 2. The dielectric functions (a), absorption coefficient (b), refractive index (c), extinction coefficient (d) and optical conductivity (e) of $\mathrm{Al}$ doped $\mathrm{ZnO}$.

The optical properties of a thin film (refractive index $n(\lambda)$, absorption coefficient $\alpha(\lambda)$, extinction coefficient $k(\lambda)$, dielectric functions $\varepsilon(\lambda)$, optical conductivity $\sigma(\lambda)$ and thickness $d$ ) can be easily evaluated from a transmission spectrum with interference effects using the envelope method [26-31] (Fig. 2). This method is applicable in the case of a weakly absorbing thin film on an entirely transparent substrate that is much thicker than the thin film. These conditions are met in this work.

\subsection{Theoretical results}

To analyze the properties of the Al-doped structure was used a $3 \times 3 \times 3$ supercell which including $54 \mathrm{Zn}$ atoms and $54 \mathrm{O}$ atoms and present in Fig. 3. In our supercell model, one $\mathrm{Zn}$ atom is substituted with one dopant aluminum atom which corresponds to the impurity concentration close to 1.85 at. $\%$. After structure relaxation the lattice parameters $\mathrm{ZnO}: \mathrm{Al}$ were $a=b=$ $3.462 \AA$ and $c=5.663 \AA$, which are bigger than for pure $\mathrm{ZnO}(a=b=3.251 \AA$ and $c=5.213$ [21]). Also, the $\mathrm{Zn}-\mathrm{O}$ bond lengths for $\mathrm{ZnO}$ : $\mathrm{Al}$ was $2.08 \AA$ which is longer than those of the pure $\mathrm{ZnO}$ (1.98 $\AA$ [22]), and the Al-O bond length was $1.86 \AA$ that is shorter than the $\mathrm{Zn}-\mathrm{O}$ bond lengths. All changes of structure geometry for Al-doped $\mathrm{ZnO}$ related to the smaller ionic radius of $\mathrm{Al}^{3+}(0.54 \AA)$ compared with replaced $\mathrm{Zn}$ ion $(0.74 \AA)$. The calculated Mulliken population analysis showed that for $\mathrm{ZnO}: \mathrm{Al}$ the atomic population of $\mathrm{Al}$ was $1.60 e$ and is bigger than of $\mathrm{Zn}$ which is $0.94 e$ [22] and indicates that the valence of $\mathrm{Al}$ is larger than of $\mathrm{Zn}$. The higher valence of $\mathrm{Al}$ also leads to higher values of $\mathrm{Al}-\mathrm{O}$ bond population $(0.47 e)$ compared with the $\mathrm{Zn}-\mathrm{O}$ bond 


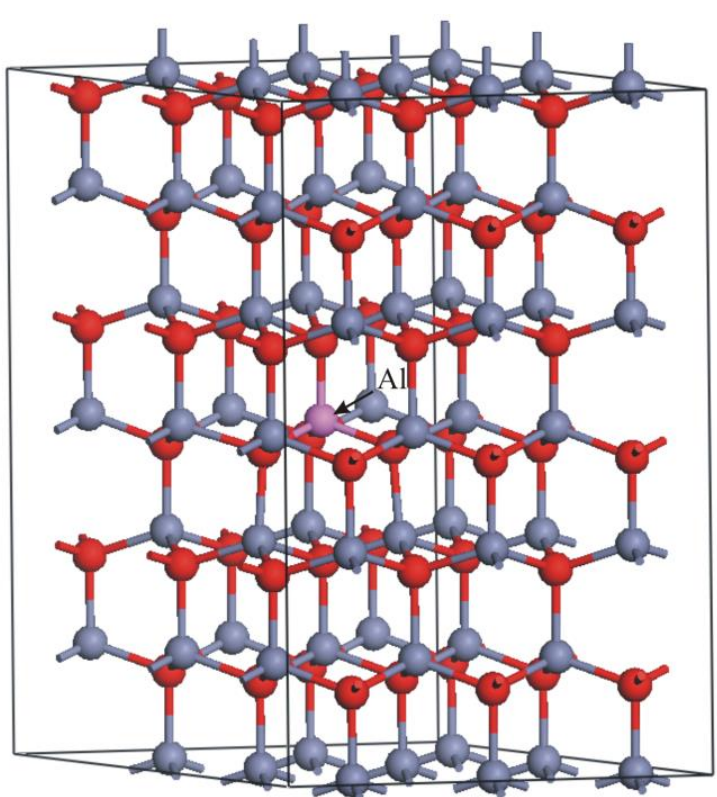

Fig. 3. The supercell model of Al doped-ZnO. Grey, red and pink balls display the zinc, oxygen, and aluminum atoms, respectively.

population of pure $\mathrm{ZnO}(0.40 e)$.

Next, we investigated the electronic properties of $\mathrm{ZnO}$ : Al. The calculated band structure of this model is presented in Fig. 4. The Fermi level is set to $0 \mathrm{eV}$. The Al-doped $\mathrm{ZnO}$ displayed n-type conduction as indicates shifted up into conduction band of the Fermi level, and refers to a well-known effect of the Burstein-Moss [32]. At the bottom of the conduction band, the occupied states can be considered as an additional energy barrier that needed overcome before the electron can be excited from the valence band to the conduction band. This energy barrier is also known as the optical band gap and denotes the energy region from the top of the valence band to the Fermi level. The optical bandgap of the $\mathrm{ZnO}$ : $\mathrm{Al}$ is $3.43 \mathrm{eV}$ which is bigger than for pure $\mathrm{ZnO}$ calculated using the same GGA+U method (3.4 eV [22]). At the same time, it should be noted that the fundamental band gap is $3.3 \mathrm{eV}$ which is smaller compared with undoped $\mathrm{ZnO}$.

$\mathrm{a}$

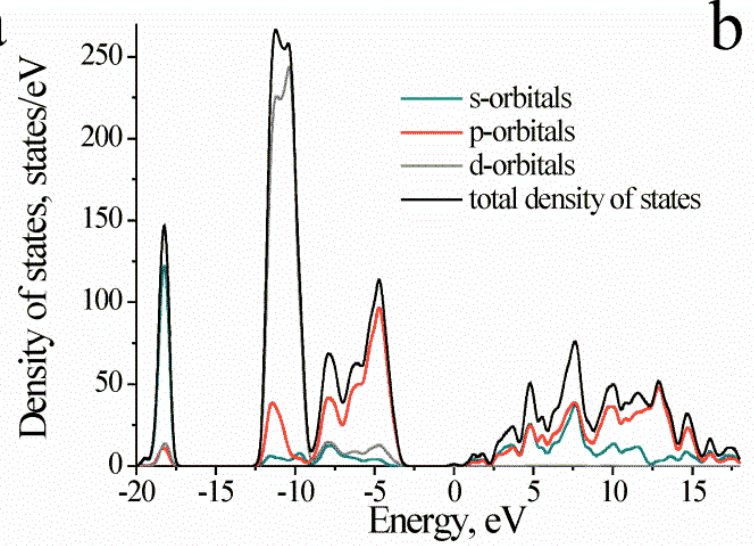

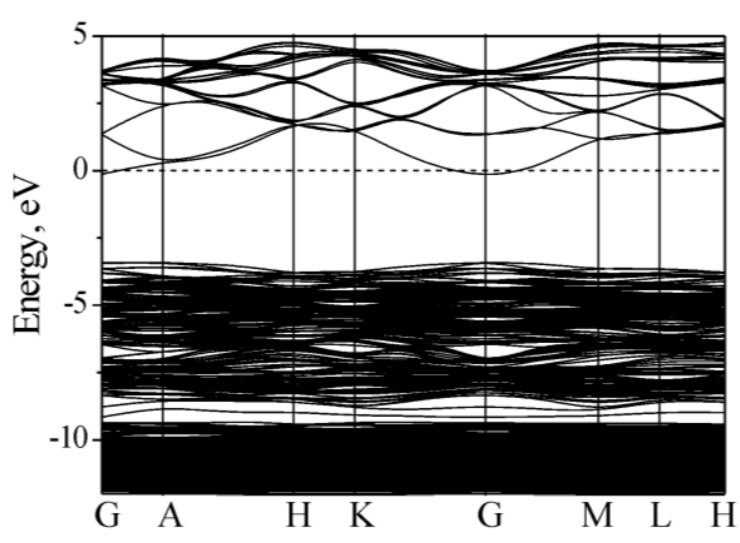

Fig. 4. The band structure of $\mathrm{Al}$ doped- $\mathrm{ZnO}$.

Fig. 5a presented the partial density of states (PDOS) of Al-doped $\mathrm{ZnO}$. As can be seen, the calculation results showed the major contribution to the PDOS in the conduction band close by the Fermi level derived from the $s$-orbitals of the $\mathrm{Al}$ atom. Moreover, the $s$-contribution in the PDOS at the impurity ion place is considerably larger than that of the $\mathrm{Zn}$ atom and leads to an improved electron conductivity of the $\mathrm{ZnO}: \mathrm{Al}$ (Fig. 5b).

To investigate the optical properties of the $\mathrm{ZnO}$ : $\mathrm{Al}$ system the dielectric function $\varepsilon(\omega)=\varepsilon_{1}+i \varepsilon_{2}$ was calculated. Ordinarily, the electronic band structure is directly related with $\varepsilon_{2}(\omega)$ (imaginary part of dielectric function) and it can be calculated by add together all probable occupied states to the unoccupied states of transitions. The $\varepsilon_{2}(\omega)$ was calculated from the following expression:

$$
\varepsilon_{2}(\omega)=\frac{2 e^{2} \pi}{\Omega \varepsilon_{0}} \sum_{k, v, c}\left|\left\langle\psi_{k}^{c}|\widehat{u} \times r| \psi_{k}^{v}\right\rangle\right| \delta\left(E_{k}^{c}-E_{k}^{v}-E\right),
$$

where $\omega$ is the frequency of light, $\Omega$ is the volume of a unit cell, $u$ is polarization vector, $\psi_{k}^{c}$ and $\psi_{k}^{v}$ are the wave functions of valence and conduction bands, respectively. The real part of dielectric function $\varepsilon_{1}(\omega)$ can be calculated using Kramers-Kronig relation, based on $\varepsilon_{2}$ $(\omega)$ :

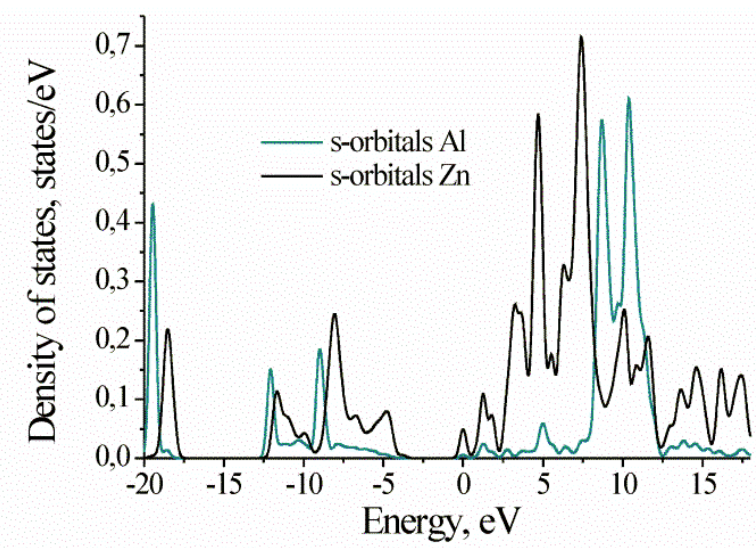

Fig. 5. The partial density of states of Al-doped $\mathrm{ZnO}$ (a) and the partial density of s-orbital of $\mathrm{Al}$ and $\mathrm{Zn}$ (b). 


$$
\varepsilon_{1}(\omega)=1+\frac{2}{\pi} p \int_{0}^{\infty} \frac{\omega^{\prime} \varepsilon_{2}\left(\omega^{\prime}\right)}{\omega^{\prime 2}-\omega^{2}} d \omega^{\prime}
$$

where $p$ indicates the main value of integral. The other optical functions, e.g. absorption coefficient $\alpha(\omega)$, refractive index $n(\omega)$, extinction coefficient $k(\omega)$ and optical conductivity $\sigma(\omega)$ can be determined by $\varepsilon_{1}(\omega)$ and $\varepsilon_{2}(\omega)$ [33].

Fig. 6 displayed the real $\varepsilon_{1}$ and imaginary part $\varepsilon_{2}$ of $\mathrm{Al}$-doped $\mathrm{ZnO}$ for different polarization vector of light. If compared the theoretical results with the experimental ones presented above (Fig. 2a), we can be seen that the main trend is well consistent with the experimental results. But it is necessary to note the shift of a curve upwards energy region compared with experimental curves because the difference between experimental and theoretical band gaps received.

The adsorption and conductivity spectrum of Al-doped $\mathrm{ZnO}$ is presented in Fig. 7a. As in the case of the dielectric function, the theoretical adsorption spectrum tendency well agrees with the experimental spectrum that is displayed in Fig. 2b. Similar results were obtained in the case of conductivity (Fig. 7b).

For the full display of experimental results (Fig. 2), we additionally calculated the refractive index and extinction coefficient of $\mathrm{Al}$-doped $\mathrm{ZnO}$ that are presented in Fig. 8.

b

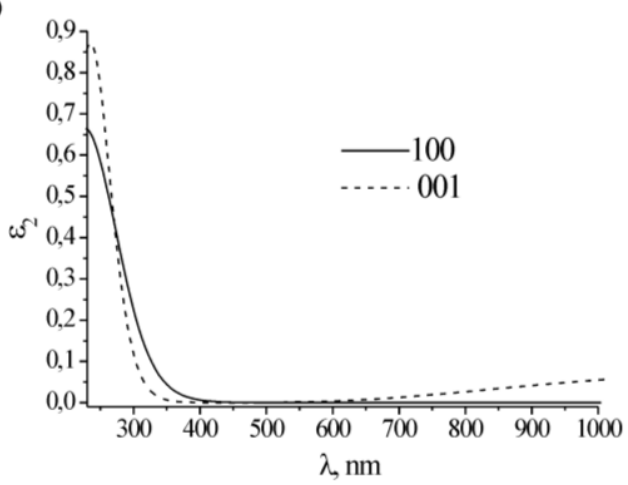

Fig. 6. The real $\varepsilon_{1}$ (a) and imaginary part $\varepsilon_{2}$ (b) of Al-doped $\mathrm{ZnO}$.

a

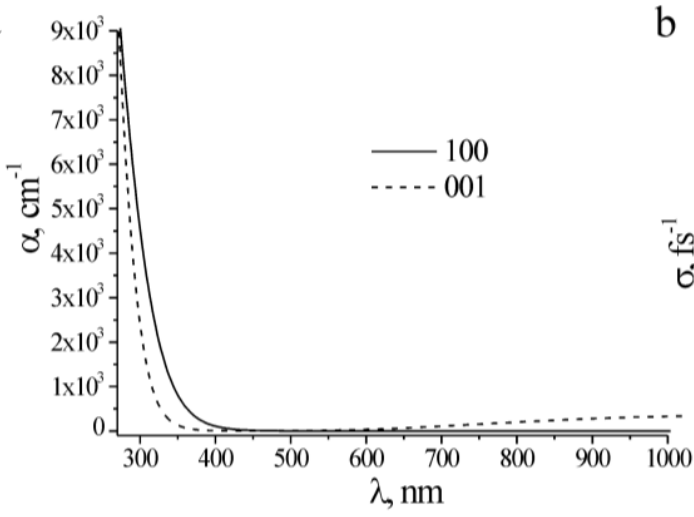

b

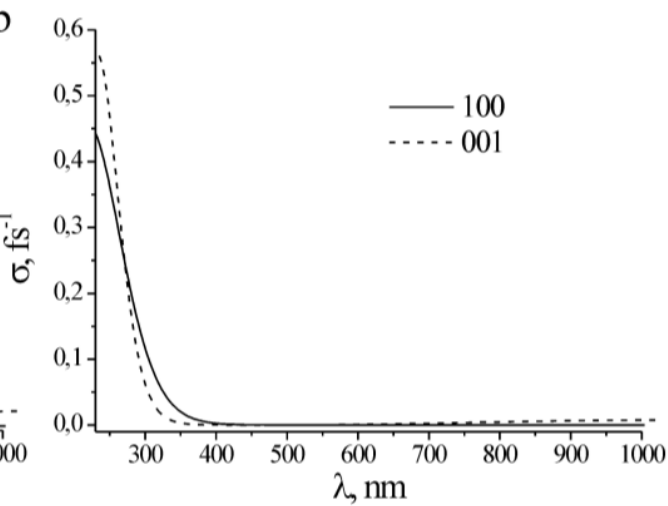

Fig. 7. The adsorption (a) and optical conductivity (b) spectrum of $\mathrm{ZnO}$ : $\mathrm{Al}$.
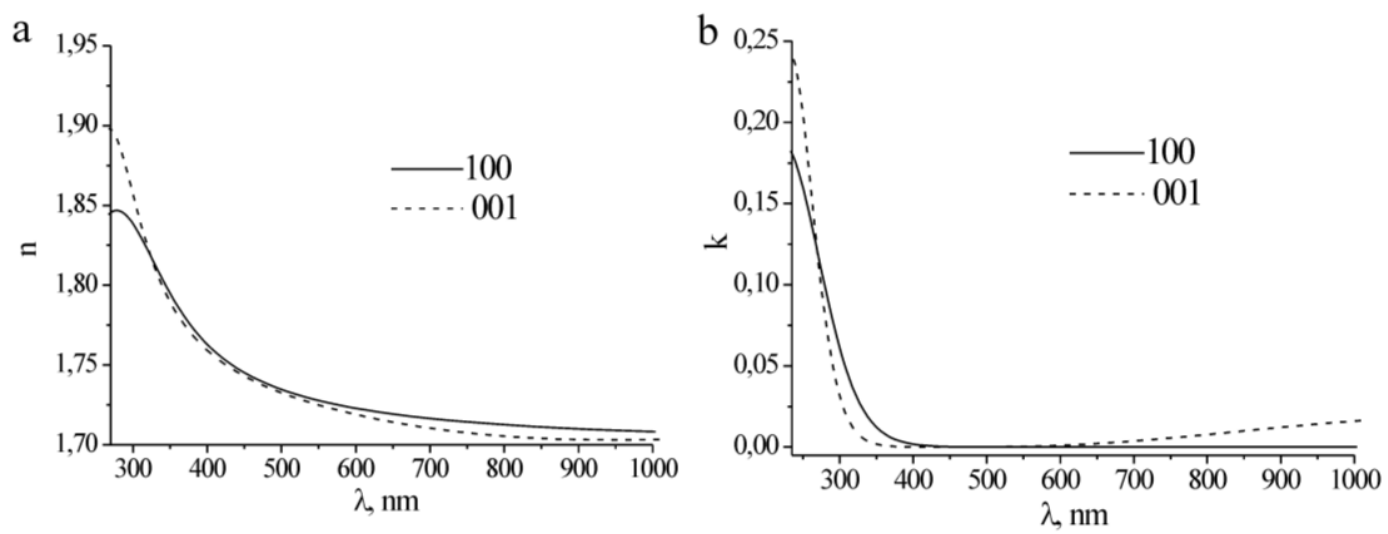

Fig. 8. The refractive index (a) and extinction coefficient (b) of $\mathrm{ZnO}$ : $\mathrm{Al}$. 


\section{Conclusions}

In this work, the electronic and optical properties of Al-doped $\mathrm{ZnO}$ were studied by means of experimental and first-principles calculation approaches. The Al-doped $\mathrm{ZnO}$ thin films were grown using the high-frequency magnetron sputtering method. The X-ray analysis approves that the major phase of the prepared samples is the wurtzite structure without secondary phases observed and $\mathrm{Al}$ is well incorporated within the $\mathrm{ZnO}$ lattice. Additionally, the DFT+U study is used for calculating the band structure of $\mathrm{Al}$-doped $\mathrm{ZnO}$. It was found that adding an $\mathrm{Al}$ atom into $\mathrm{ZnO}$ enables changes of the $\mathrm{ZnO}$ band structure. New states at the top of the valence band, derived from the interaction of valence electrons of $\mathrm{Zn}$, $\mathrm{O}$, and $\mathrm{Al}$ atoms. The change of the band structure and PDOS of the $\mathrm{ZnO}$ after $\mathrm{Al}$ doping means that the doped system may show distinct optical properties. It is important to note that the theoretically obtained results are in good agreement with experimental observations, and the appropriate properties received by calculations for $\mathrm{Al}$-doped $\mathrm{ZnO}$ were also established in the actual materials.

\section{Acknowledgements}

This work was supported by the Project of Young Scientists (ДБ/Сенсор) of Ukraine.

Kovalenko M. - $\mathrm{PhD}$ in Physical and Mathematical Sciences, Associate Professor of Solid-State Physics Department;

Bovgyra O. - $\mathrm{PhD}$ in Physical and Mathematical Sciences, Associate Professor of Solid-State Physics Department;

Dzikovskyi V. - PhD student of Solid-State Physics Department;

Kashuba F. - PhD in Physical and Mathematical Sciences, Senior Research Fellow;

Ilchuk $\boldsymbol{H}$. - Doctor of Physical and Mathematical Sciences, Professor of General Physics Department;

Petrus R. - PhD in Physical and Mathematical Sciences, Associate Professor of General Physics Department;

Semkiv I. - PhD in Physical and Mathematical Sciences, Research Assistant.

[1] C.R.A. Catlow, S.A. French, A.A. Sokol, A.A. Al-Sunadi and S.M. Woodley, J. Comput. Chem. 29, 2234 (2008) (https://doi.org/10.1002/jcc.21051).

[2] Ü. Özgür, Y.I. Alivov, C. Liu, A. Teke, M.A. Reshchikov, S. Do_gan, V. Avrutin, S.-J. Cho, and H. Morkoc, J. Appl. Phys. 98, 041301 (2005) (https://doi.org/10.1063/1.1992666).

[3] Y.S. Lee, Y.C. Peng, J.H. Lu, Y.R. Zhu, H.C. Wu, Thin Solid Films 570, 464 (2014) (https://doi.org/10.1016/j.tsf.2014.04.037).

[4] H. Kumarakuru, D. Cherns and A.M. Collins, Ceramic International 40, 8389 (2014) (https://doi.org/10.1016/j.ceramint.2014.01.045).

[5] V. Devi, M. Kumar and D.K. Shukla, Superlattices and Microstructures 83, 431 (2015) (https://doi.org/10.1016/j.spmi.2015.03.047).

[6] A.A. Al-Ghamdi, O.A. Al-Hartomy and M.El Okr, Spectrochimica Acta Part A: Molecular and Biomolecular Spectroscopy 131, 512 (2014) (https://doi.org/10.1016/j.saa.2014.04.020).

[7] R. Petrus, H. Ilchuk, A. Kashuba, I. Semkiv, E. Zmiiovska, F. Honchar, R. Lys, Journal of Nano- and Electronic Physics 11(3), 03020 (2019). (https://doi.org/10.21272/jnep.11(3).03020).

[8] R.Y. Petrus, H.A. Ilchuk, A.I. Kashuba, I.V. Semkiv, E.O. Zmiiovska, Optics and Spectroscopy 126(3), 220 (2019) (https://doi.org/10.1134/S0030400X19030160).

[9] P. Giannozzi, O. Andreussi, T. Brumme, O. Bunau, M.B. Nardelli, M. Calandra, R. Car, C. Cavazzoni, D. Ceresoli, and M. Cococcioni, J. Phys. Condens. Matter 29, 465901 (2017) (https://doi.org/10.1088/1361648X/aa8f79).

[10] D. Vanderbilt, Phys. Rev. B 41, 7892 (1990) (https://doi.org/10.1103/PhysRevB.41.7892).

[11] C.G. Broyden, IMA Journal of Applied Mathematics 6(3), $222 \quad$ (1970) (https://doi.org/10.1093/imamat/6.3.222).

[12] R. Fletcher, The Computer Journal 24(3), 23 (1970) (https://doi.org/10.1093/comjnl/13.3.317).

[13] D. Goldfarb, Mathematics of Computation 24, 23 (1970) (https://doi.org/10.1090/S0025-5718-1970 -0258249-6).

[14] D.F. Shanno, Mathematics of Computation 24, 647 (1970) (https://doi.org/10.1090/S0025-5718-19700274029-X).

[15] N.N. Lathiotakis, A.N. Andriotis, M. Menon, Phys. Rev. B 78, 193311 (2008) (https://doi.org/10.1103/PhysRevB.78.193311).

[16] R.M. Sheetz, I. Ponomareva E. Richter, A.N. Andriotis, M. Menon, Phys. Rev. B 80, 195314 (2009) (https://doi.org/10.1103/PhysRevB.80.195314).

[17] A. Walsh, J.L.F. Da Silva, S.H. Wei, Phys. Rev. Lett. 100, 256401 (2008) (https://doi.org/10.1103/PhysRevLett.100.256401).

[18] O.V. Bovgyra, M.V. Kovalenko, V.Ye. Dzikovskyi, A.P. Vaskiv, M.Ya. Sheremeta, Journal of Nano- and Electronic Physics 12(5), 05003 (2020) (https://doi.org/10.21272/jnep.12(5).05003).

[19] X. Qu, S. Lü, D. Jia, S. Zhou, Q. Meng, Materials Science in Semiconductor Processing 16(4), 1057 (2013) (https://doi.org/10.1016/j.mssp.2013.04.002). 
[20] A. Mang, K. Reimann, St. Rübenacke, Solid State Commun. 94, 251 (1995). (https://doi.org/10.1016/00381098(95)00054-2).

[21] O. Bovgyra, M. Kovalenko, R. Bovhyra, V. Dzikovskyi, Journal of Physical Studies 23(4), 4301 (2019) (https://doi.org/10.30970/jps.23.4301).

[22] M. Kovalenko, O. Bovgyra, A. Franiv, V. Dzikovskyi, Materials Today: Proceeding (2019) (https://doi.org/10.1016/j.matpr.2019.11.274).

[23] O. Bovgyra, M. Kovalenko, V. Dzikovskyi, and M. Moroz, IEEE 2nd Ukraine Conference on Electrical and $\begin{array}{llll}\text { Computer Engineering (UKRCON), } \quad \text { (Lviv, } & \text { Ukraine, }\end{array}$ (https://doi.org/10.1109/UKRCON.2019.8879928).

[24] O.V. Bovgyra and M.V. Kovalenko, Journal of Nano- and Electronic Physics 8(2), 2031 (2016) (https://doi.org/10.21272/jnep.8(2).02031).

[25] M.V. Kovalenko, O.V. Bovgyra, V.Ye. Dzikovskyi, R.V. Bovhyra, Nanosistemi, Nanomateriali, Nanotehnologii 18(3), 727 (2020).

[26] L.I. Nykyruy, R.S. Yavorskyi, Z.R. Zapukhlyak, G. Wisz, P. Potera, Optical Materials 92, 319 (2019) (https://doi.org/10.1016/j.optmat.2019.04.029).

[27] R.Yu. Petrus, H.A. Ilchuk, A.I. Kashuba, I.V. Semkiv, E.O. Zmiiovska, F.M. Honchar, Journal of Applied Spectroscopy 87(1), 35 (2020) (https://doi.org/10.1007/s10812-020-00959-7).

[28] R. Petrus, H. Ilchuk, A. Kashuba, I. Semkiv, E. Zmiiovska, Funct. Mater. 27(2), 342 (2020) (https://doi.org/10.15407/fm27.02.342).

[29] R. Yavorskyi, L. Nykyruy, G. Wisz, P. Potera, S. Adamiak and Sz.Górny, Applied Nanoscience (Switzerland) 9, 715 (2018) (https://doi.org/10.1007/s13204-018-0872-z).

[30] H. Ilchuk, R. Petrus, A. Kashuba, I. Semkiv and E. Zmiiovska, Molecular Crystals and Liquid Crystals 699(1), 1 (2020) (https://doi.org/10.1080/15421406.2020.1732532).

[31] A. Kashuba, H. Ilchuk, R. Petrus, I. Semkiv, O. Bovgyra, M. Kovalenko and V. Dzikovskyi, Modern Physics Letters B 33, 2150189 (2021) (https://doi.org/10.1142/S021798492150189X).

[32] R. Ebrahimifard, M.R. Golobostanfard, H. Abdizadeh, Applied Surface Science 290, 252 (2014) (https://doi.org/10.1016/j.apsusc.2013.11.062).

[33] S. Saha, T.P. Sinha, A. Mookerjee, Physical Review B: Condensed Matter 62, 8828 (2000) (https://doi.org/10.1103/PhysRevB.62.8828).

\section{М. Коваленко ${ }^{1,2}$, А. Кашуба ${ }^{2}$, О. Бовгира ${ }^{1}$, В. Дзіковський ${ }^{1,2}$, Г. Ільчук ${ }^{2}$ Р. Петрусь ${ }^{2}$, I. Семків ${ }^{2}$}

\section{Вплив легування атомів Al на оптичні властивості тонких плівок ZnO: теорія та експеримент}

\footnotetext{
${ }^{1}$ Львівький національний університет імені Івана Франка, Львів, Украӥна, mariya.kovalenko@lnu.edu.иа
}

${ }^{2}$ Національний університет «Львівська Політехніка», Львів, Украӥна, andriykashuba07@gmail.com

Проведено дослідження впливу легування атомами алюмінію на структурні, електронні і оптичні властивості тонких плівок оксиду цинку, використовуючи експериментальні методи та розрахунки в межах теорії функціонала густини. Зміни властивостей легованих тонких плівок, які були нанесенні на скляну підкладку методом високочастотного магнетронного розпилення, контролювалися за допомогою даних X-променевої дифракції та спектрів пропускання. Результати теоретичних розрахунків показують, що електронна структура ZnO:Al добре узгоджується з експериментальними даними при використанні методу DFT + U. На основі спектрів пропускання визначено оптичні константи для легованих плівок, такі як діелектрична проникність, показник заломлення, ширина оптичної забороненої зони, коефіцієнт екстинкції та оптична провідність. Результати розрахунків показали, що при внесенні домішкового атома $\mathrm{Al}$ в суперкомірку $\mathrm{ZnO}$, спостерігається зміна параметрів цієї гратки. Ширина оптичної забороненої зони $\mathrm{ZnO}: \mathrm{Al}$ зростає порівняно 3 нелегованим $\mathrm{ZnO}$. Крім того, навколо рівня Фермі, в $\mathrm{ZnO}: \mathrm{Al}$, виникають неглибокі донорні рівні, які переважно походять від 3s-орбіталей Al. Результати наших розрахунків оптичних властивостей $\mathrm{ZnO}$, легованого $\mathrm{Al}$, в межах DFT, задовільно узгоджуються з експериментально виміряними значеннями коефіцієнта пропускання.

Keywords: легований $\mathrm{ZnO}$, DFT+U, ширина оптичної забороненої зони, зонно-енергетична структура, оптичні властивості. 